\title{
Crucial cross-talk of interleukin-1 $\beta$ and progesterone in human choriocarcinoma
}

\author{
ELENA ZACHARIADES ${ }^{1}$, DIONISIS MPARMPAKAS ${ }^{1}$, PETER THOMAS $^{2}$, \\ MARIANN RAND-WEAVER ${ }^{1}$ and EMMANOUIL KARTERIS ${ }^{1}$ \\ ${ }^{1}$ Centre for Cell Chromosome Biology, Biosciences, Centre for Cell and Chromosome Biology, \\ School of Health Sciences and Social Care, Brunel University, Uxbridge, UB8 3PH, UK; \\ ${ }^{2}$ Marine Science Institute, University of Texas at Austin, Port Aransas, TX 78373, USA
}

Received August 24, 2011; Accepted October 3, 2011

DOI: 10.3892/ijo.2012.1349

\begin{abstract}
Choriocarcinoma is a highly malignant epithelial tumour that is most often associated with hydatidiform mole and presents the most common emergency medical problem in the management of trophoblast disease. We hypothesise that the hormones/cytokines present within the tumour microenvironment play key roles in the development of choriocarcinoma. In this study we assessed the effects of interleukin-1 $\beta$ (IL-1 $\beta$ ) on cell death in the presence or absence of the sex hormone progesterone using two choriocarcinoma cell lines (BeWo and JEG-3) as in vitro experimental models. Although IL-1 $\beta$ induced cell death in both cell lines, the effect was more pronounced in JEG-3 cells, where cell death reached $40 \%$ compared to $15 \%$ in BeWo cells. Cell death of JEG-3 cells in response to IL-1 $\beta$ was significantly decreased by co-treatment with $100 \mathrm{nM}$ and $1000 \mathrm{nM}$ progesterone and completely abolished at a progesterone concentration of $1000 \mathrm{nM}$. Progesterone was also able to induce phosphorylation of $\mathrm{ERK}_{1 / 2}$ in these cells. Pretreatment of JEG-3 cells with a specific MAPK inhibitor (UO126) inhibited progesterone's inhibitory effect on cell death. Collectively, these data provide evidence of cross-talk between progesterone and IL- $1 \beta$ in this aggressive and poorly understood tumour that involves activation of a MAPK pathway and involvement of numerous progesterone receptors.
\end{abstract}

\section{Introduction}

Gestational trophoblastic tumors are a group of diseases in which cancer (malignant) cells grow in the tissues that are formed following conception. They span from a benign hydatidiform mole, through an invasive mole to a highly malignant form of choriocarcinoma. Choriocarcinoma is malignant (both

Correspondence to: Dr Emmanouil Karteris, Centre for Cell Chromosome Biology, Biosciences, School of Health Sciences and Social Care, Brunel University, Uxbridge, UB8 3PH, UK

E-mail: emmanouil.karteris@brunel.ac.uk

Key words: choriocarcinoma, interleukin-1 $\beta$, progesterone, progesterone receptor histologically and clinically) and is one of the most frequent emergency medical issues in the management disease of trophoblastic origin. The clinical symptoms vary, ranging from bleeding when the disease is localized in the uterus to a diverse repertoire of symptoms from metastases with the central nervous system, lungs, and liver the most frequent sites of secondary tumour formation. Therefore, choriocarcinomas present certain diagnostic challenges (1).

Gestational choriocarcinoma is a highly malignant epithelial tumour that is most often associated with hydatidiform mole. On the occasions that pathology is available the characteristic findings exhibit the structure of the villous trophoblast but with sheets of syncytiotrophoblast or cytotrophoblast cells, haemorrhage, necrosis and intravascular growth are also common. A number of studies have shown involvement of certain tumourassociated genes in choriocarcinoma (1). For example, p53 oncoprotein immunoreactivity was significantly stronger in choriocarcinoma than in normal placenta (2). Studies from the same group revealed that c-myc, c-erbB-2, c-fms and bcl-2 oncoproteins may be important in the pathogenesis of complete mole and choriocarcinoma since they appear to be overexpressed in this aggressive tumour (3). The cellular mdm2 gene, which has a potential transforming activity that can be activated by overexpression, is also abundantly present in choriocarcinomas (4). Interestingly, a protein termed NECC1 is absent in choriocarcinomas whereas it is expressed in large amounts in the placenta and the uterus (5). Macrophage-derived cytokines have also been implicated in trophoblastic diseases. For example, circulating levels of interleukin-1 $\beta$ (IL-1 $\beta$ ), interleukin-6 (IL-6) and tumour necrosis factor $\alpha$ (TNF- $\alpha$ ) are elevated in choriocarcinomas (6).

From an endocrine perspective, choriocarcinoma is not an inert tumour as it secrets a wide repertoire of hormones. However, apart from extensive studies on human chorionic gonadotropin (hCG) very little is known about the involvement of sex hormones. Indeed, emerging studies suggest that progesterone-mediated responses appear to affect breast and ovarian cancers. Recent data point towards mechanisms of progesterone receptor (PR) inhibition of inflammatory responses in cellular models of breast cancer (7). Hardy et al found that progesterone appears to inhibit the effects of IL-1 $\beta$ in myometrial cells (8). Subsequent studies from the same group indicated that PR plays an important anti-inflammatory role in breast cancer cells via 
ligand-dependent and ligand-independent mechanisms (9). In poorly differentiated endometrial cancer cells, treatment of progesterone downregulated gene expression of IL-1 $\beta$ (10). This is of particular interest, since a high IL-1 $\beta$ content is often associated with tumour invasiveness and with other pathologic features suggestive of aggressive tumour biology (11).

We hypothesise that the hormones/cytokines present within the tumour microenvironment play a key role for the development of choriocarcinoma. In this study we assessed the effects IL-1 $\beta$ can exert in the presence or absence of progesterone and provide novel evidence of crosstalk in this aggressive and poorly understood tumour.

\section{Materials and methods}

Cell culture. BeWo and JEG-3 cell lines were purchased from the European Collection of Cell Cultures (ECACC, Salisbury, UK). The cells were maintained at standard culture conditions of $5 \%$ $\mathrm{CO}_{2}$ in air at $37^{\circ} \mathrm{C}$. BeWo cells were cultured in Ham F12 (SigmaAldrich, UK) containing $10 \%$ heat-inactivated fetal bovine serum (FBS), and $0.5 \%$ penicillin-streptomycin; whereas, JEG-3 cells were maintained in MEME (Sigma-Aldrich) containing $10 \%$ heat-inactivated FBS, and $0.5 \%$ penicillin-streptomycin, $0.5 \%$ L-glutamine, $0.5 \%$ sodium pyruvate and $0.5 \%$ MEM nonessential amino acids.

Trypan blue exlusion assay. BeWo and JEG-3 cells were maintained in cell culture as described above. Cells were seeded in 6-well multi dishes for treatment purposes. Once confluence was achieved, the media was aseptically removed and the cells were rinsed with $1 \mathrm{X}$ PBS. A known volume of phenol red-free media containing only $100 \mu \mathrm{g} / \mathrm{ml}$ of penicillin and $100 \mu \mathrm{g} / \mathrm{ml}$ of streptomycin (Gibco) was added to the cells $24 \mathrm{~h}$ prior starting the treatments. The cells where incubated for $24 \mathrm{~h}$ with the specific compounds prior to starting the trypan blue exclusion assay.

Treatments. The following overnight treatments were used for the in vitro studies: progesterone (P4) at concentrations of $1 \mathrm{nM}$, $10 \mathrm{nM}, 100 \mathrm{nM}, 1000 \mathrm{nM}$. Promegestone (R5020), a specific agonist of nuclear progesterone receptor, at a concentration of $30 \mathrm{nM}$. This concentration was carefully selected, as dose above the $30 \mathrm{nM}$ appear to activate membrane progesterone receptors. Both agents were applied in the absence or presence of IL- $1 \beta$ $(10 \mathrm{ng} / \mu \mathrm{l})$. It should be noted that U0126 compound was used to pre-treat the cells for $30 \mathrm{~min}$ before continuing with any other treatments. The selective MAPK inhibitor was used at a concentration of $1 \mu \mathrm{M}$.

RNA isolation and cDNA synthesis. Total ribonucleic acid (RNA) was isolated using an RNA extraction kit (SigmaAldrich, UK), according to manufacturer's instructions. RNA concentration was determined by spectrophotometric analysis (NanoDrop; Thermo Scientific, UK) and agarose gel electrophoresis. RNA (500 ng) was reverse-transcribed into cDNA using $5 \mathrm{IU} / \mu \mathrm{l}$ RNase $\mathrm{H}$ reverse transcriptase (Invitrogen, $\mathrm{UK}$ ).

Quantitative RT-PCR. Relative expression of the genes of interest was assessed by quantitative PCR (Q-PCR) on an ABI Prism 7900HT Sequence detection system (Applied Biosystems) using SYBR ${ }^{\circledR}$ Green-PCR reaction mixture (Sigma-Aldrich) and specific primers (Table I). As a negative control, distilled water was used in place of the cDNA. For the quantitative PCR, the following equations were used: $\Delta \mathrm{Ct}=\mathrm{Ct}_{\text {(gene of interest) }}-\mathrm{Ct}_{\text {(house }}$ keeping gene),$\Delta \Delta \mathrm{Ct}=\Delta \mathrm{Ct}_{\text {(sample) }}-\Delta \mathrm{Ct}_{\text {(calibrator) }}$, Relative Quantity $(R Q)=2^{-\Delta \Delta C t}$. RQ value was set up as 1 for the untreated (no supplement) BeWo and JEG-3 cells. We have also calculated the gene expression levels as RQ values, using the untreated control for each cell line as a calibrator. We did so, since RQ values provide a more accurate comparison between the initial amounts of template in each sample, without requiring an exact copy number for analysis. Q-PCR data are reported as the mean \pm SEM. Statistical analysis of the $\Delta \Delta \mathrm{Ct}$ values was performed by one-way analysis of variance (ANOVA), followed by Bonferroni Multiple Comparison as a post-hoc test using GraphPad Prism 5.0.

Immunofluorescent analysis. JEG-3 cells were fixed in 4\% paraformaldehyde for 10 min prior to washes in PBS and incubation with $10 \%$ bovine serum albumin (BSA) for $1 \mathrm{~h}$. Cells were incubated for $1 \mathrm{~h}$ with antibodies against mPRs, PR-B, and PGRMC-1 as previously described (12). Images were captured using a Plan Apo Neofluor 63X NA 1.25 oil objective (Zeiss) on a Zeiss Axiovert $200 \mathrm{M}$ microscope and viewed using AxioVision software. Images were taken at a set exposure time.

Western immunoblotting. Samples were separated on an SDS-10\% polyacrylamide gel and the proteins were transferred to a nitrocellulose membrane. The membrane was blocked in TBS containing 5\% dried milk powder (w/v) and $0.1 \%$ Tween-20, for $1 \mathrm{~h}$ at room temperature. After three washes with TBS- $0.1 \%$ Tween-20, the nitrocellulose membranes were incubated with primary antibodies against phospho- and total ERK $\mathrm{ER}_{1 / 2}$ (Santa Cruz Biotechnology, USA). The primary antiserum was used at a 1:250 dilution overnight at $4^{\circ} \mathrm{C}$. The membranes were washed thoroughly for $30 \mathrm{~min}$ with TBS- $0.1 \%$ Tween, before incubation with the secondary HRP-conjugated immunoglobulin (1:2000) for $1 \mathrm{~h}$ at room temperature and further washing for $30 \mathrm{~min}$ with TBS-0.1\% Tween-20. Antibody complexes were visualised as previously described (12). The immunoreactive bands were analyzed using Image J 1.34s image-analysis software (National Institute of Health, USA). Data are presented as mean \pm SD. Statistical comparisons between the different treatments were performed using the Student's t-test. Differences among means were considered significant when $\mathrm{p}<0.05$.

\section{Results}

Effects of progesterone on BeWo and JEG-3 choriocarcinoma cells. Serum starved cells were treated in a dose-dependent manner over $24 \mathrm{~h}$ with progesterone. Controls, with unstimulated cells were included in order to establish a 'baseline' of cell death in our experimental model. Significantly lower percentages of dead cells were seen when BeWo cells were treated with $10 \mathrm{nM}, 100 \mathrm{nM}$ and $1000 \mathrm{nM}$ of progesterone compared to the untreated BeWo cells (Fig. 1A). When JEG-3 cells were treated, significance in terms of increased cell death was achieved only at $100 \mathrm{nM}$ and $1000 \mathrm{nM}$ (Fig. 1B).

Progesterone reverses $I L-1 \beta$-induced cell death. When cells were treated with IL-1 $\beta$, cell death was induced in both cell 
Table I. The primers used for Q-PCR experiments.

\begin{tabular}{llll}
\hline $\begin{array}{l}\text { Gene of } \\
\text { interest }\end{array}$ & \multicolumn{1}{c}{ Forward primer } & Reverse primer & $\begin{array}{c}\text { Product } \\
\text { size }(\mathrm{bp})\end{array}$ \\
\hline mPR- $\alpha$ & CGCTCTTCTGGAAGCCGTACATCTATG & CAGCAGGTGGGTCCAGACATTCAC & 100 \\
mPR- $\beta$ & AGCCTCCTACATAGATGCTGCCC & GGTGCCTGGTTCACATGTTCTTCA & 194 \\
mPR- $\gamma$ & CAGCTGTTTCACGTGTGTGTGATCCTG & GCACAGAAGTATGGCTCCAGCTATCTGAG & 120 \\
PGRMC1 & TCTGGACTGCACTGTTGTCCTTG & GCAAACACCTGTTCCTATTCTG & 290 \\
$\beta-$-actin & AAGAGAGGCATCCTCACCCT & TACATGGCTGGGGTGTTGAA & 216 \\
\hline
\end{tabular}

A.

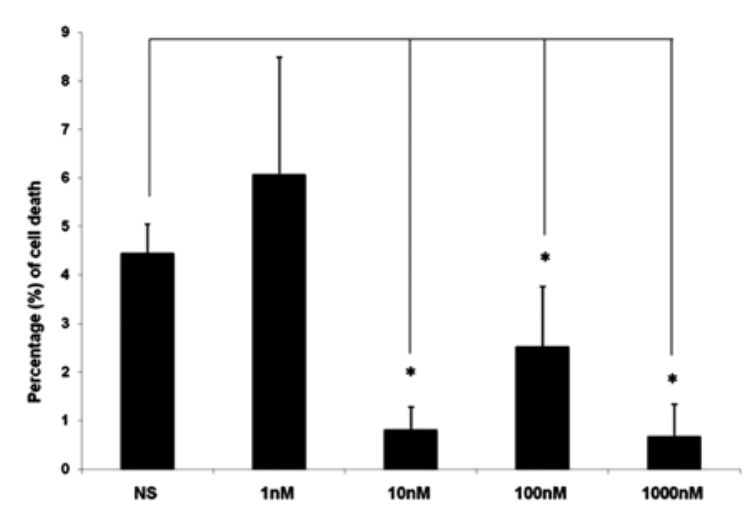

B.

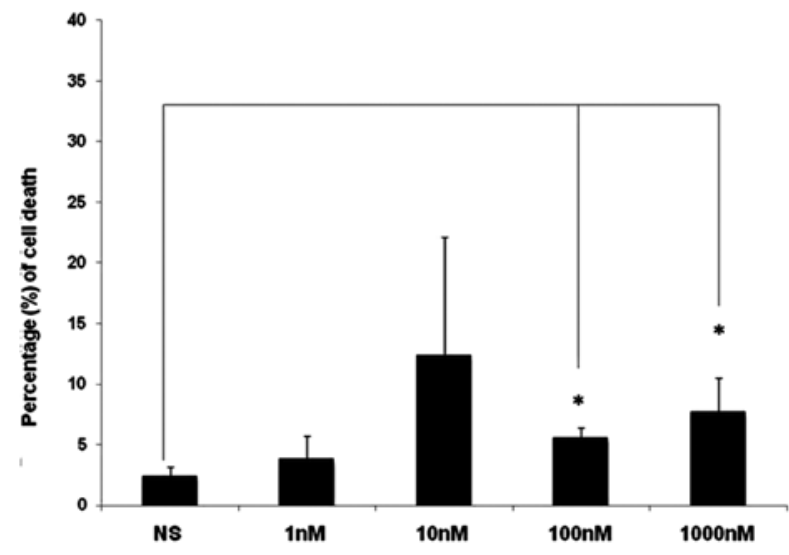

Figure 1. (A) Percentage of dead BeWo cells after treatment with various concentrations (1-1000 $\mathrm{nM}$ ) of progesterone. Each histogram represents the mean \pm SEM of three individual experiments. "Significance of various treatments with unstimulated BeWo cells. (B) Percentage of dead JEG-3 cells after treatment with various concentrations (1-1000 nM) of progesterone. Each histogram represents the mean \pm SEM of three individual experiments. "Significance of various treatments with unstimulated JEG-3 cells.

lines. However, the effect was more exacerbated in JEG-3 cells, where IL-1 $\beta$ induced $40 \%$ cell death when compared to BeWo cells that reached a modest but significant $15 \%$ cell death. When BeWo cells were treated with IL-1 $\beta$ and progesterone, there was a significant decrease in cell death at concentrations of 100 $\mathrm{nM}$ and $1000 \mathrm{nM}$ that reduced the percentage of dead cells around 10\% (Fig. 2A). Interestingly, in JEG-3 cells the effects of progesterone were far more pronounced. Progesterone at a concentration as low as $1 \mathrm{nM}$, significantly reversed the effect of IL-1 $\beta$. This effect was not dose-dependent as a range of
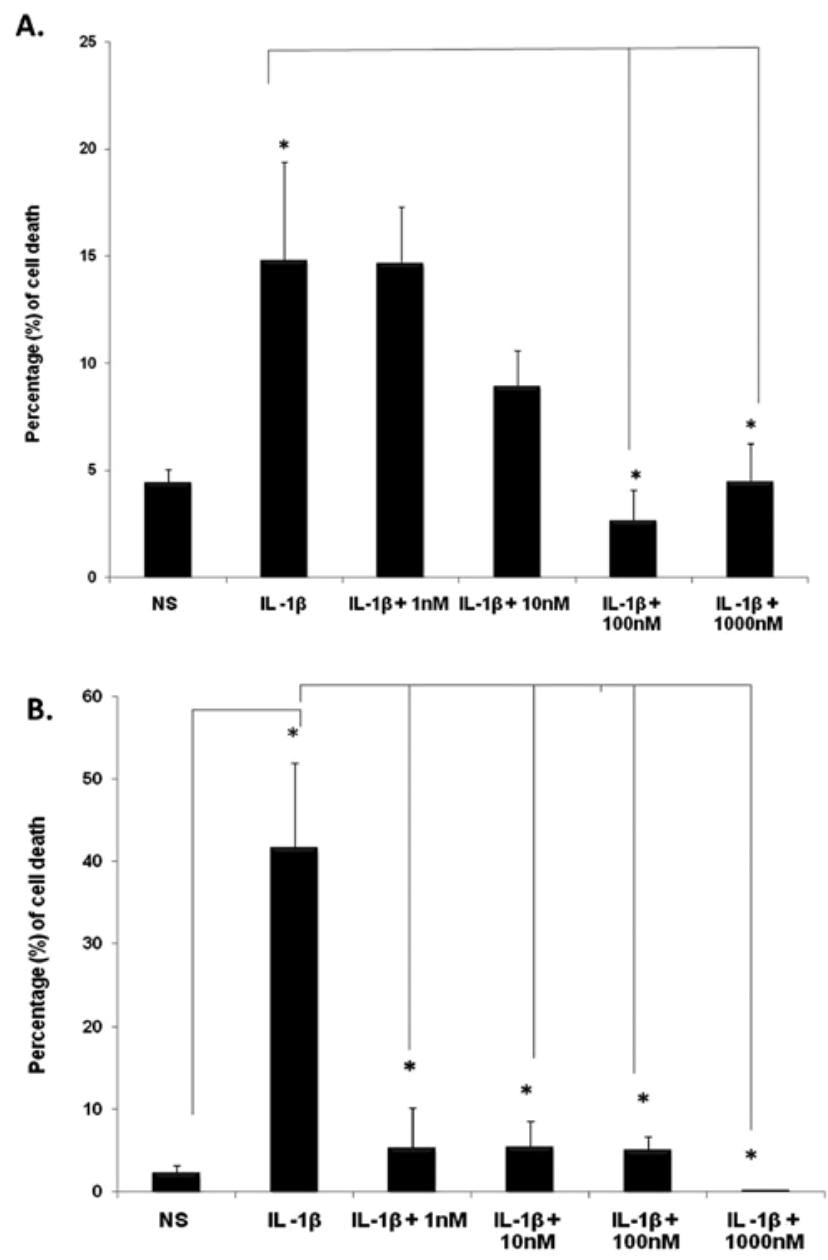

Figure 2. (A) Percentage of dead BeWo cells after treatment with IL-1 $\beta$ $(10 \mathrm{ng} / \mu \mathrm{l})$ and progesterone (1-1000 $\mathrm{nM})$. Each histogram represents the mean \pm SEM of three individual experiments. (B) Percentage of dead JEG-3 cells after treatment with IL-1 $\beta(10 \mathrm{ng} / \mu \mathrm{l})$ in the presence of progesterone $(1-1000 \mathrm{nM})$. Each histogram represents the mean \pm SEM of three individual experiments.

1-100 nM reduced cell death $30 \%$ when compared to IL-1 $\beta$ treatment alone. When cells were treated with the supraphysiological dose of $1000 \mathrm{nM}$, the IL-1 $\beta$ effect was completely abolished (Fig. 2B).

Progesterone and $R 5020$ alter the phosphorylation of ERK $K_{1 / 2}$ in choriocarcinoma cells. ERK $_{1 / 2}$ appears to play a key role in promoting cytotrophoblast cell differentiation and proliferation. As a result we assessed the effects of progesterone and R5020 on the phosphorylation of $\mathrm{ERK}_{1 / 2}$ correcting over total-ERK $\mathrm{K}_{1 / 2}$ 
A.

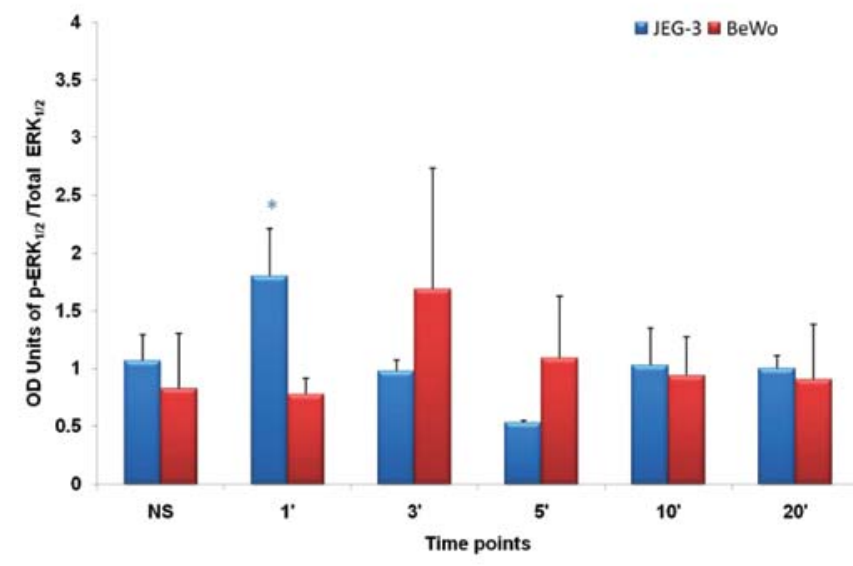

B.

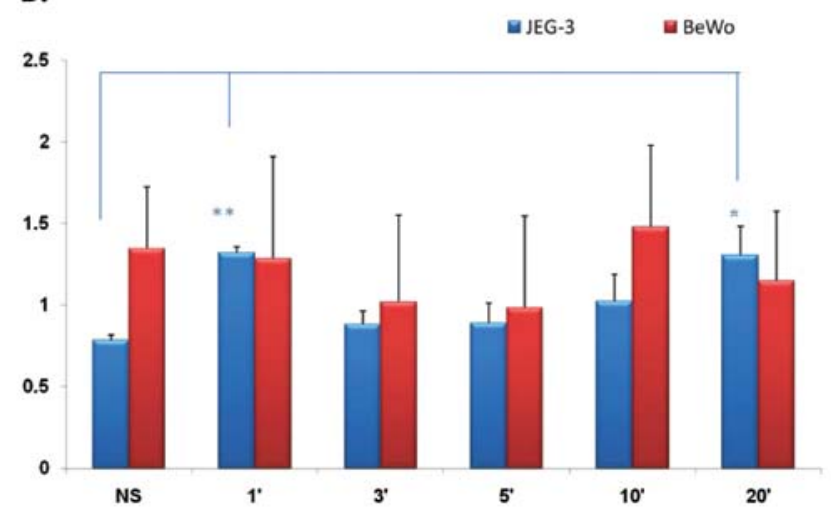

Figure 3. (A) Densitometric analysis of phosphorylated $E K_{1 / 2}$ protein normalized to total $\mathrm{ERK}_{1 / 2}$ protein and reported as optical density (OD) units + SEM. JEG-3, BeWo cells were treated with $100 \mathrm{nM}$ of progesterone. (B) Densitometric analysis of phosphorylated $\mathrm{ERK}_{1 / 2}$ protein normalized to total $\mathrm{ERK}_{1 / 2}$ protein and reported as optical density (OD) units mean \pm SEM. JEG-3, BeWo cells were treated with $30 \mathrm{nM}$ of R5020.

levels. The cells were treated with progesterone and R5020, for $1,3,5,10$ and $20 \mathrm{~min}$. The expression of $\mathrm{p}-\mathrm{ERK}_{1 / 2}$ was normalised to total MAPK and the optical density values of immunoreactive bands are presented in Fig. 3. When compared to the non-supplement (NS) control, a significant increase of the phoshporylation level was evident when JEG-3 cells were treated with $\mathrm{P} 4$ for $1 \mathrm{~min}$. When BeWo cells were treated at identical time points, progesterone did not induce any significant changes in the phosporylation status of $\mathrm{ERK}_{1 / 2}$ (Fig. 3A). There were no substantial changes even after $1 \mathrm{~h}$ of treatment (data not shown). However, it should be noted that a progesteroneinduced phosphorylation at 3 min post-treatment just failed to reach significance. Given the effect seen with progesterone, we have used the specific nuclear PR activator R5020 in order to dissect this response further. R5020 induced a significant increase in phosphorylation of $\mathrm{ERK}_{1 / 2}$ after 1 and $20 \mathrm{~min}$ of treatment when compared to the non-supplement. Similarly, in BeWo-treated cells, R5020 did not alter the phorphorylation of ERK $_{1 / 2}$ significantly (Fig. 3B). Collectively, these data strongly suggest involvement of the nuclear PR in this response.

Involvement of MAPK signalling in the progesterone-induced cell death. Given the changes in the phosphorylation of $\mathrm{ERK}_{1 / 2}$,
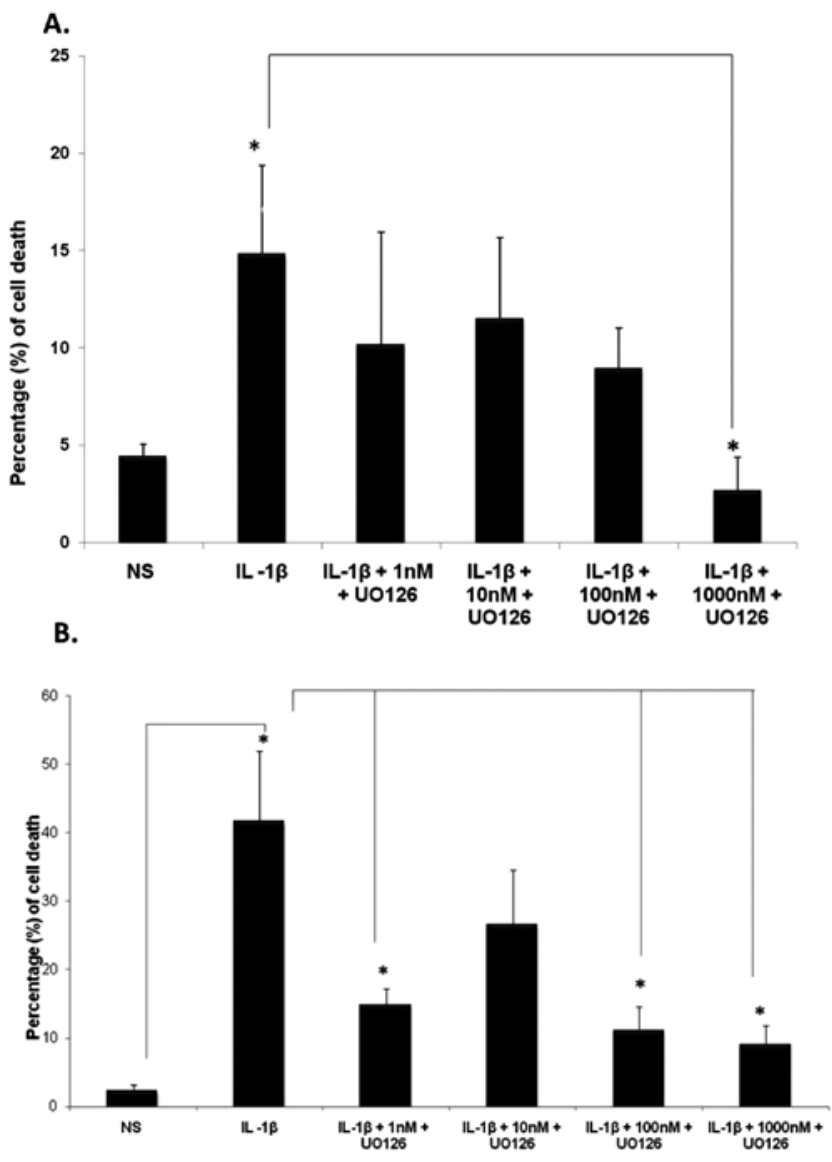

Figure 4. (A) Percentage of dead BeWo cells after treatment with IL-1 $\beta$ $(10 \mathrm{ng} / \mu \mathrm{l})$, pre-treating cells with UO126 $(1 \mu \mathrm{M})$ and various concentrations $(1-1000 \mathrm{nM})$ of progesterone. Each histogram represents the mean \pm SEM of three individual experiments. (B) Percentage of dead JEG-3 cells after treatment with IL-1 $\beta(10 \mathrm{ng} / \mu \mathrm{l})$, pre-treating cells with UO126 $(1 \mu \mathrm{M})$ and various concentrations (1-1000 nM) of progesterone. Each histogram represents the mean \pm SEM of three individual experiments.

we hypothesised that the MAPK pathway might be implicated in the progesterone mediated responses. In order to dissect this response, cells were pretreated with the selective MAPK inhibitor UO126 for $30 \mathrm{~min}$ prior to further hormonal challenges. In BeWo cells pretreatment with UO126 reversed the effect of progesterone at $100 \mathrm{nM}$ and significantly inhibited the $1000 \mathrm{nM}$ effect in presence of IL-1 $\beta$ (Fig. 4A). Interestingly, UO126 also inhibited substantially the progesterone effect seen in JEG-3 cells. In particular, in JEG-3 cells that were treated with $10 \mathrm{nM}$ progesterone, UO126 completely abolished the IL-1 $\beta$ effect (Fig. 4B).

An interesting picture emerged when cells were treated with R5020 in the presence or absence of UO126 and IL-1 1 . In BeWo cells, R5020 alone did not affect the cell death induced by IL-1 $\beta$. However, when cells were pretreated with UO126, an induction of cell death was noted (Fig. 5A). In JEG-3 cells, R5020 reducedcell death in the presence of IL-1 $\beta$ but UO126 was unable to reverse this effect (Fig. 5B). Collectively these data suggest that the MAPK pathway is involved only when multiple progesterone receptors are activated by progesterone.

Differential regulation of $m P R s$ and PGRMC-1 by $I L-1 \beta$ and progesterone. Following the differential responses of progesterone 

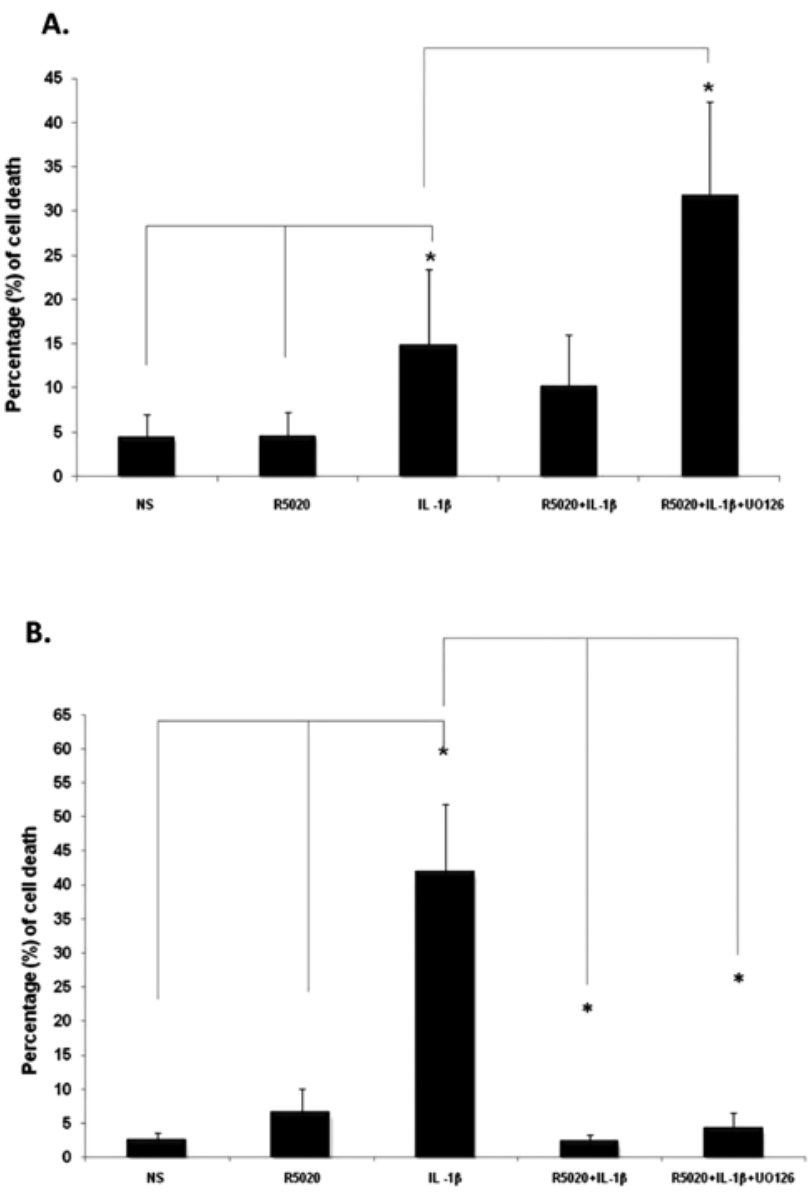

Figure 5. (A) Percentage of dead BeWo cells after treatment with IL-1 $\beta$ $(10 \mathrm{ng} / \mu \mathrm{l})$, pre-treating cells with UO126 $(1 \mu \mathrm{M})$ and $30 \mathrm{nM}$ of R5020. Each histogram represents the mean \pm SEM of three individual experiments. (B) Percentage of dead JEG-3 cells after treatment with IL-1 $\beta(10 \mathrm{ng} / \mu \mathrm{l})$, pre-treating cells with UO126 $(1 \mu \mathrm{M})$ and $30 \mathrm{nM}$ of R5020. Each histogram represents the mean \pm SEM of three individual experiments.

and R5020, we hypothesised that other progesterone receptors might be implicated in these events. Therefore, we investigated the combined effects of progesterone and IL-1 $\beta$ in an attempt to mimic the hormonal-cytokine cross-talk in a tissue microenvironment. When BeWo cells were treated with progesterone and IL-1 $\beta$, all mPRs and PGRMC-1 were downregulated (Fig. 6). However, this effect did not reach significance. In JEG-3 cells the combined treatment downregulated $\mathrm{mPR} \alpha$ and had no apparent effect on $\mathrm{mPR} \gamma$ (Fig. 6A and C). However, it induced a dramatic upregulation of $\mathrm{mPR} \beta$ and a significant (2-fold) upregulation of PGRMC-1 (Fig. 6B and D.

\section{Discussion}

A number of studies so far have linked the gestational choriocarcinoma with alterations in tumor suppressor genes, oncogenes or other imprinting genes (13). This study addresses some of the unresolved issues in the area of cancer endocrinology, as we provide novel evidence of a cross-talk of an inflammatory cytokine and a sex steroid hormone in choriocarcinoma.

IL- $1 \beta$ is a proinflammatory cytokine which at the early stages of pregnancy is produced and secreted by the maternal decidua (14). This cytokine may potentially be an inducer of
A.

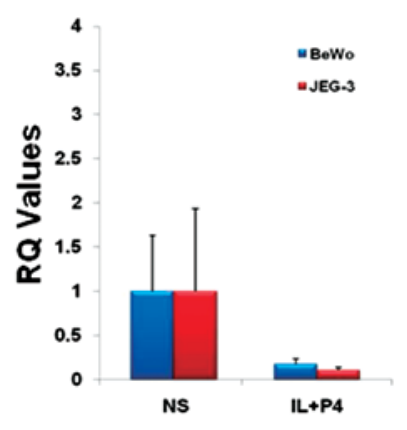

C.

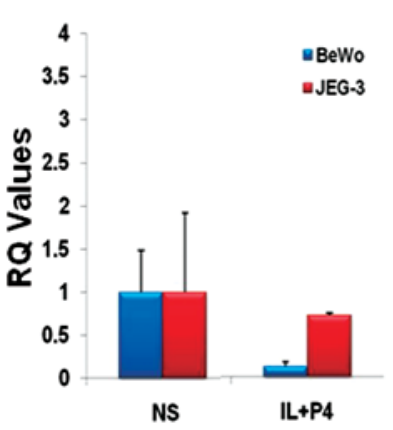

B.

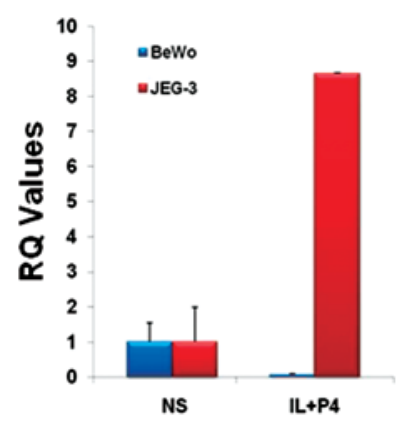

D.

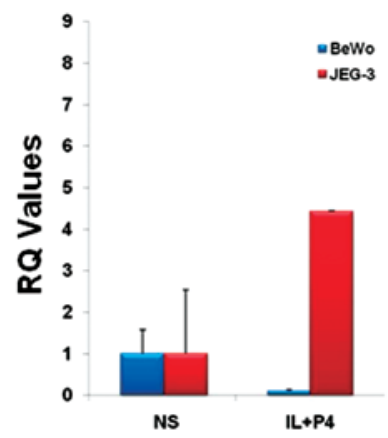

Figure 6. (A) RQ values of the expression of $\mathrm{mPR} \alpha$ in BeWo and JEG-3 cells after treating with IL-1 $\beta(10 \mathrm{ng} / \mu \mathrm{l})$ and $100 \mathrm{nM}$ of progesterone. Each histogram represents the mean $\pm\left[2^{-\Delta \Delta \mathrm{SD}}(+)-2^{-\Delta \Delta \mathrm{SD}}(-)\right]$ of three individual experiments. (B) $\mathrm{RQ}$ values of the expression of $\mathrm{mPR} \beta$ in BeWo and JEG- 3 cells after treating with IL-1 $\beta(10 \mathrm{ng} / \mu \mathrm{l})$ and $100 \mathrm{nM}$ of progesterone. Each histogram represents the mean $\pm\left[2^{-\Delta \Delta S D}(+)-2^{-\Delta \Delta S D}(-)\right]$ of three individual experiments. (C) RQ values of the expression of $\mathrm{mPR} \gamma$ in BeWo and JEG-3 cells after treating with IL-1 $\beta$ $(10 \mathrm{ng} / \mu \mathrm{l})$ and $100 \mathrm{nM}$ of progesterone. Each histogram represents the mean $\pm\left[2^{-\Delta \Delta S D}(+)-2^{-\Delta \Delta S D}(-)\right]$ of three individual experiments. (D) RQ values of the expression of PGRMC-1 in BeWo and JEG-3 cells after treating with IL-1 $\beta$ $(10 \mathrm{ng} / \mu \mathrm{l})$ and $100 \mathrm{nM}$ of progesterone. Each histogram represents the mean \pm $\left[2^{-\Delta \Delta \mathrm{SD}}(+)-2^{-\Delta \Delta \mathrm{SD}}(-)\right]$ of three individual experiments.

placental trophoblast invasion by stimulating the release of metalloproteinase (MMP-9) by human placental cytotrophoblast (15). Also it has been associated with trophoblast cell differentiation by increasing the production of hCG hormone in isolated first trimester villous trophoblast (16) as well as in human choriocarcinoma cells (17). Of interest, there is an increase in production of hCG in gestational choriocarcinomas.

Here we provide a novel insight of the role of IL-1 $\beta$ and progesterone within the tumour microenvironment. In both in vitro models, IL-1 $\beta$ appears to increase cell death, whereas progesterone exerts a protective effect on serum starvationinduced and IL-1 $\beta$-induced cell death. In higher doses of progesterone, there is a clear shift towards proliferative effects (data not shown). To the best of our knowledge this is the first study that implicates IL-1 $\beta$ and progesterone as dual regulators of choriocarcinoma. Previous studies have shown that IL-1 $\beta$ on its own mediated apoptosis of placental cells (18). Similarly, our data showing protective effects against cell death are consistent with previous findings that show anti-apoptotic effects of progesterone in granulosa cells of the ovary, where this effect 

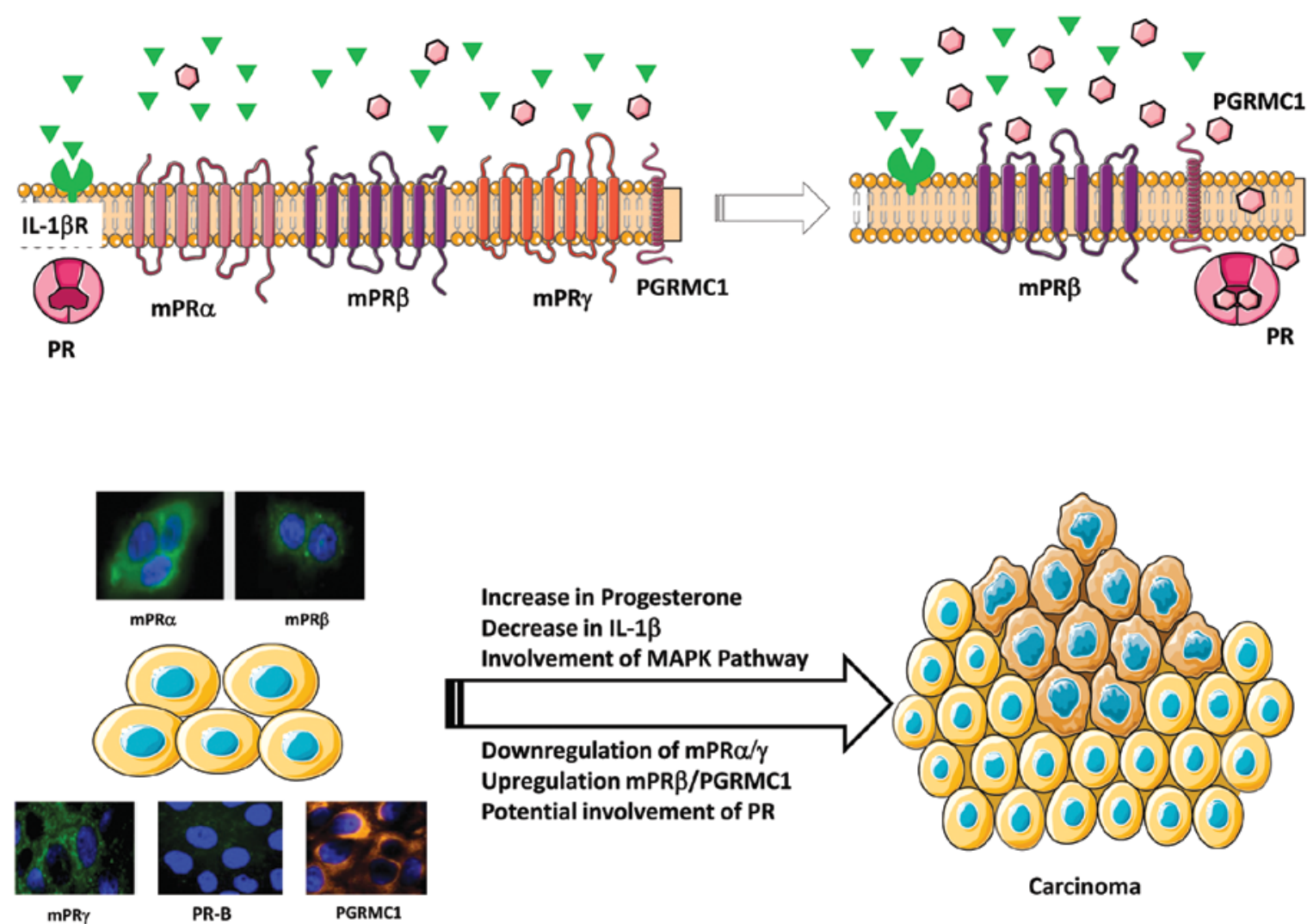

Figure 7. Schematic representation of our hypothesis: increase of progesterone within the cellular microenvironment shifts the proliferation dynamics towards events that involve MAPK and numerous progesterone receptors to stimulate tumorigenesis.

was PR-specific and was reversed when RU486, an antiprogestin was used (19). Also progesterone induced suppression of apoptosis in the rat mammary gland during lactation (20). However, apart from one study that shows tremendous fluctuations of serum progesterone in choriocarcinoma $(1.3-182.9 \mathrm{ng} / \mathrm{ml})(21)$ there is no further data regarding with relation to trophoblastic diseases.

Compared to the BeWo cells the JEG-3 cells upon treatment with the cytokine showed a higher percentage of dead cells. This may be the result of an upregulation of interleukin 1 receptor, which according to an extensive microarray analysis in both cell lines, was shown to be present only in the JEG-3 cells accounting for the sensitivity shown to this cytokine (22). Upon co-treatment of JEG-3 cells with IL-1 $\beta$ and progesterone a reduction in the percentage of cell death is seen in comparison to the cytokine only treated cells. A dramatic reduction is seen when $1000 \mathrm{nM}$ of P4 is used. It should be taken into consideration that since treatment was for $24 \mathrm{~h}$ it is plausible that P4 could activate multiple PRs. This indeed appears to be the case, since treatment of JEG-3 cells with R5020 also induced a significant drop in cell death, indicative of involvement of nuclear PRs in this process.

The MAP kinase family controls a wide range of cellular events such as the process of cell differentiation, cell proliferation, and cell death as well as regulating short-term process required for homeostasis and hormonal responses (23). Suppression of ERK $_{1 / 2}$ activity early in the differentiation process leads to an impaired trophoblast differentiation process as the levels of hCG secretion were dramatically reduced compared to non-experimental culture conditions (24). Rapid activation of $\mathrm{ERK}_{1 / 2}$ was detected in JEG-3 cells upon stimulation with $\mathrm{P} 4$ and the nuclear progesterone receptor agonist R5020 as early as 1 min of treatment. Rapid stimulation of ERK activity has also been previously reported, upon 2 min of treatment with R5020 in T47D cells (25). The responses of progesterone in BeWo cells were more subtle and did not reach significance. This is not surprising, as microarray data show that approximately $20 \%$ of genes represented on a microarray analysis were differentially expressed in JEG-3 and BeWo choriocarcinoma cell lines (22). This JEG-3 specific rapid activation of $\mathrm{ERK}_{1 / 2}$ can be attributed as the result of upregulation of genes involved in the MAPK cascade in JEG-3 cells in comparison to BeWo cells. Genes that have been shown to be upregulated include the mitogen-activated protein kinase kinase kinase 7 interacting protein 2 (MAP3K7IP2) mitogenactivated protein kinase kinase kinase kinase 1 (MAP4K1), mitogen-activated protein kinase 1 (MAPK1), mitogen-activated protein kinase 14 (MAPK14), mitogen-activated protein kinase 3 (MAPK3), GRB2-associated binding protein 1 (GAB1) and Son of sevenless homolog 1 (SOS1) (22). Thus, the progestin induced rapid ERK $_{1 / 2}$ phosphorylation in JEG-3 compared to BeWo can be a direct result of an overexpressed MAPK signalling pathway. The potential involvement of the MAPK in these events has been further dissected using the specific inhibitor U0126. Again, the effect was far more pronounced in JEG-3 cells, where treatment 
with U0126 inhibited substantially the progesterone effect in the presence of IL-1 $\beta$.

The anti-apoptotic effects of P4 cannot be attributed to be solidly mediated by PRs, as other putative mediators of the action of progesterone have been shown to be expressed, such as the mPRs (26) and PGRMC-1 (27). Treatment of JEG-3 cells with progesterone and IL- $1 \beta$ exerted a differential effect on these alternative membrane receptors. The most significant effect was the dramatic upregulation of $\mathrm{mPR} \beta$ and PGRMC- 1 . This is of particular interest given the involvement of PGRMC-1 in cancer progression and tumourigenesis $(28,29)$. Moreover, it is attractive to speculate that mPRs are also involved in this response since Dressing et al have shown that progestins can mediate antiapoptotic effects, via $\mathrm{mPR} \alpha$, in ovarian follicle cells (30).

Based primarily on our findings on the more responsive choriocarcinoma cell line JEG-3 we would like to propose the following model: when IL-1 $\beta$ is the predominant cytokine within the tumour microenvironment, it modulates proliferative responses by inducing cell death. However, when the dynamics change and there is a surge of progesterone this result to an upregulation of PGRMC- 1 and mPR $\beta$. The net effect is occupation of both membrane and nuclear progesterone receptors that involving the MAPK pathway inhibit cell death and predispose cells for malignant transformation.

\section{Acknowledgements}

This research was funded by a National Institutes of Health Grant ESO12961.

\section{References}

1. Shih IM: Gestational trophoblastic neoplasia - pathogenesis and potential therapeutic targets. Lancet Oncol 8: 642-650, 2007.

2. Fulop V, Mok SC, Genest DR, Gati I, Doszpod J and Berkowitz RS $\mathrm{p} 53, \mathrm{p} 21, \mathrm{Rb}$ and $\mathrm{mdm} 2$ oncoproteins. Expression in normal placenta, partial and complete mole, and choriocarcinoma. J Reprod Med 43: 119-127, 1998.

3. Fulop V, Mok SC, Genest DR, Szigetvari I, Cseh I and Berkowitz RS: c-myc, c-erbB-2, c-fms and bcl-2 oncoproteins. Expression in normal placenta, partial and complete mole, and choriocarcinoma. J Reprod Med 43: 101-110, 1998.

4. Landers JE, Haines DS, Strauss JF III and George DL: Enhanced translation: a novel mechanism of $\mathrm{mdm} 2$ oncogene overexpression identified in human tumor cells. Oncogene 9: 2745-2750, 1994.

5. Asanoma K, Matsuda T, Kondo H, Kato K, Kishino T, Niikawa N, Wake $\mathrm{N}$ and Kato $\mathrm{H}$ : NECC1, a candidate choriocarcinoma suppressor gene that encodes a homeodomain consensus motif. Genomics 81: 15-25, 2003.

6. Shaarawy M and Darwish NA: Serum cytokines in gestational trophoblastic diseases. Acta Oncol 34: 177-182, 1995.

7. Kobayashi S, Stice JP, Kazmin D, Wittmann BM, Kimbrel EA, Edwards DP, Chang CY and McDonnell DP: Mechanisms of progesterone receptor inhibition of inflammatory responses in cellular models of breast cancer. Mol Endocrinol 24: 2292-2302, 2010.

8. Hardy DB, Janowski BA, Corey DR and Mendelson CR: Progesterone receptor plays a major anti-inflammatory role in human myometrial cells by antagonism of nuclear factor-kappaB activation of cyclooxygenase 2 expression. Mol Endocrinol 20: 2724-2733, 2006.

9. Hardy DB, Janowski BA, Chen CC and Mendelson CR: Progesterone receptor inhibits aromatase and inflammatory response pathways in breast cancer cells via ligand-dependent and ligand-independent mechanisms. Mol Endocrinol 22: 1812-1824, 2008 .
10. Davies S, Dai D, Wolf DM and Leslie KK: Immunomodulatory and transcriptional effects of progesterone through progesterone $\mathrm{A}$ and $\mathrm{B}$ receptors in Hec50co poorly differentiated endometrial cancer cells. J Soc Gynecol Investig 11: 494-499, 2004.

11. Jin L, Yuan RQ, Fuchs A, Yao Y, Joseph A, Schwall R, Schnitt SJ Guida A, Hastings HM, Andres J, Turkel G, Polverini PJ, Goldberg ID and Rosen EM: Expression of interleukin-1beta in human breast carcinoma. Cancer 80: 421-434, 1997.

12. Zachariades E, Foster H, Goumenou A, Thomas P, RandWeaver $\mathrm{M}$ and Karteris E: Expression of membrane and nuclear progesterone receptors in two human placental choriocarcinoma cell lines (JEG-3 and BeWo): Effects of syncytialization. Int J Mol Med 27: 767-774, 2011

13. Cheung AN, Zhang HJ, Xue WC and Siu MK: Pathogenesis of choriocarcinoma: clinical, genetic and stem cell perspectives. Future Oncol 5: 217-231, 2009.

14. Romero R, Wu YK, Brody DT, Oyarzun E, Duff GW and Durum SK: Human decidua: a source of interleukin-1. Obstet Gynecol 73: 31-34, 1989.

15. Librach CL, Feigenbaum SL, Bass KE, Cui TY, Verastas N, Sadovsky Y, Quigley JP, French DL and Fisher SJ: Interleukin-1 beta regulates human cytotrophoblast metalloproteinase activity and invasion in vitro. J Biol Chem 269: 17125-17131, 1994.

16. Yagel S, Lala PK, Powell WA and Casper RF: Interleukin-1 stimulates human chorionic gonadotropin secretion by first trimester human trophoblast. J Clin Endocrinol Metab 68: 992-995, 1989.

17. Seki H, Zosmer A, Elder MG and Sullivan MHF: The regulation of progesterone and hCG production from placental cells by interleukin-1ß. Biochim Biophys Acta 1336: 342-348, 1997.

18. Nilkaeo A and Bhuvanath S: Interleukin-1 modulation of human placental trophoblast proliferation. Mediators Inflamm 2006: 79359, 2006.

19. Peluso JJ and Pappalardo A: Progesterone mediates its antimitogenic and anti-apoptotic actions in rat granulosa cells through a progesterone-binding protein with gamma aminobutyric acida receptor-like features. Biol Reprod 58: 1131-1137, 1998.

20. Berg MN, Dharmarajan AM and Waddell BJ: Glucocorticoids and progesterone prevent apoptosis in the lactating rat mammary gland. Endocrinology 143: 222-227, 2002.

21. Dawood MY: Serum progesterone and serum human chorionic gonadotropin in gestational and nongestational choriocarcinoma. Am J Obstet Gynecol 123: 762-765, 1975.

22. Burleigh DW, Kendziorski CM, Choi YJ, Grindle KM, Grendell RL, Magness RR and Golos TG: Microarray analysis of BeWo and JEG3 trophoblast cell lines: identification of differentially expressed transcripts. Placenta 28: 383-389, 2007.

23. Lewis TS, Shapiro PS and Ahn NG: Signal transduction through MAP kinase cascades. Adv Cancer Res 74: 49-139, 1998.

24. Daoud G, Amyot M, Rassart E, Masse A, Simoneau L and Lafond J: ERK1/2 and p38 regulate trophoblasts differentiation in human term placenta. J Physiol 566: 409-423, 2005.

25. Migliaccio A,Piccolo D, Castoria G, Di Domenico M, Bilancio A, Lombardi M, Gong W, Beato M and Auricchio F: Activation of the $\mathrm{Src} / \mathrm{p} 21 \mathrm{ras} /$ Erk pathway by progesterone receptor via crosstalk with estrogen receptor. EMBO J 17: 2008-2018, 1998.

26. Zhu Y, Bond J and Thomas P: Identification, classification, and partial characterization of genes in humans and other vertebrates homologous to a fish membrane progestin receptor. Proc Natl Acad Sci USA 100: 2237-2242, 2003.

27. Meyer C, Schmid R, Scriba PC and Wehling M: Purification and partial sequencing of high-affinity progesterone-binding site(s) from porcine liver membranes. Eur J Biochem 239: 726-731, 1996.

28. Neubauer H, Yang Y, Seeger H, Fehm T, Cahill MA, Tong X, Ruan X and Mueck AO: The presence of a membrane-bound progesterone receptor sensitizes the estradiol-induced effect on the proliferation of human breast cancer cells. Menopause 18: 845-850, 2011.

29. Ahmed IS, Rohe HJ, Twist KE, Mattingly MN and Craven RJ: Progesterone receptor membrane component 1 (PGRMC-1): a heme-1 domain protein that promotes tumorigenesis and is inhibited by a small molecule. J Pharmacol Exp Ther 333: 564-573, 2010.

30. Dressing GE, Pang Y, Dong J and Thomas P: Progestin signaling through mPR $\alpha$ in Atlantic croaker granulosa/theca cell cocultures and its involvement in progestin inhibition of apoptosis. Endocrinology 151: 5916-5926, 2010. 